\title{
FATWA MUI TENTANG KHITAN PEREMPUAN
}

\author{
M. Asrorun Ni'am Sholeh \\ Komisi Nasional Perlindungan Anak Indonesia (KPAI) \\ Jl. Teuku Umar No. 10-12, Menteng, Jakarta Pusat 10011 \\ E-mail: asrorunniam@gmail.com
}

\begin{abstract}
The MUI Fatwa about Female Circumcision. The issue of female circumcision has become a public issue following research, either independent or sponsored, repeatedly finding there to be a number of negative effects arising from allowing the enforcement of female circumcision in a number of countries. The issue of children's and women's protection are also often connected to the issue of the implementation of circumcision, especially in relation to children's rights and women's reproductive rights. This study finds that provisions targeting female circumcision do so in an effort to protect women's rights. This article finds that the MUI fatwa, as well as ulamas' views on madzhab and fiqh, which regulates procedures pertaining to the implementation of female circumcision, serves to strengthen the protection of children's rights, that is, protection from negative effects which is caused by extreme actions in the dangerous practice of circumcision.
\end{abstract}

Keywords: female circumcision, MUI, fatwa, fiqh, children's protection.

Abstrak: Fatwa MUI tentang Khitan Perempuan. Masalah khitan terhadap perempuan menjadi isu publik setelah adanya pelbagai penelitian, baik yang dilakukan secara independen maupun karena ada sponsor, yang menemukan adanya pelbagai dampak negatif yang ditimbulkan dari penyimpangan pelaksanaan khitan terhadap perempuan di beberapa negara. Isu perlindungan anak dan perempuan juga sering kali dikaitkan dalam masalah pelaksanaan khitan, khususnya terkait hak anak dan hak reproduksi perempuan. Studi ini menemukan bahwa ketentuan mengenai khitan perempuan sejalan dengan upaya perlindungan terhadap hak perempuan. Fatwa MUI, sebagaimana juga pandangan ulama mazhab fikih yang mengatur tata cara pelaksanaan khitan perempuan, justru meneguhkan perlindungan terhadap hak anak, yakni perlindungan dari dampak negatif yang ditimbulkan akibat tindakan berlebihan dalam praktik khitan yang menyebabkan bahaya.

Kata Kunci: khitan, perempuan, fatwa MUI, fikih, perlindungan anak

\section{Pendahuluan}

Isu khitan perempuan menyeruak dan muncul menjadi isu publik sangat terkait dengan setidaknya dua hal. Pertama, kampanye sistemik dari lembaga donor terkait dengan upaya perlindungan hak asasi manusia dan hak anak. Termasuk hak perempuan dalam melakukan reproduksi. Kedua, sajian atas penyelewengan praktik khitan perempuan yang berdampak pada timbulnya pelbagai ekses negatif yang membahayakan (sebagaimana kasus di pelbagai negara Afrika).

Khitan dalam kajian fikih (hukum Islam) secara umum ditempatkan dalam bab ibadah, dan bahkan ada yang lebih spesifik, ditempatkan pada bagian "bersuci"1.

Received: 23rd January 2012, Revised: 16th May 2012, Accepted: 30th May 2012.

${ }^{1}$ Lihat antara lain dalam Abû Ishâq Ibrâhîm al-Syayrâzî, alMuhadzdzab, (Bayrût; Dâr al-Fikr, t.th), juz I, h. 29. Lihat juga Yahyâ ibn Syaraf al-Nawawî, al-Majmû̀, (Bayrût: Dâr al-Fikr, 1996), Cet. I, Juz II, h. 148.
Khitan, baik bagi laki-laki maupun perempuan dikaitkan dengan upaya pensucian diri, baik bersifat hissî maupun mảnawî.

Dalam tataran hukum taklîfi, ulamaberbedapendapat mengenai ketentuan hukum terkait dengan khitan, baik bagi laki-laki maupun perempuan. Secara umum, pandangan fukaha terbagi menjadi dua: kelompok yang wajib dan kelompok yang menetapkan hukum sunah. Bahkan, dalam hal khitan terhadap perempuan, ada yang "menetralkannya" dan menganggap sebagai makrûmah. ${ }^{2}$

Masalah khitan terhadap perempuan menjadi isu publik setelah adanya pelbagai penelitian, baik yang dilakukan secara independen maupun karena ada sponsor, yang menemukan adanya pelbagai dampak

${ }^{2}$ Dalam diskursus usul fikih, tidak ditemukan istilah hukum makrûmah. Dalam perspektif ini, hukum dibagi menjadi dua: hukum wadh'î dan hukum taklîfî. Hukum taklîfí terdiri atas lima hal: wajib, sunah, mubâh, makrûh, dan haram. 
negatif yang ditimbulkan dari penyimpangan ${ }^{3}$ pelaksanaan khitan terhadap perempuan di beberapa negara ${ }^{4}$.

Atas dasar fakta tersebut ${ }^{5}$, muncul rencana aksi pelarangan khitan terhadap perempuan ${ }^{6}$. Bahkan, muncul desakan agar pelarangan tersebut dituangkan dalamperaturan perundang-undangan disertaihukuman bagi pelakunya. Berkorelasi dengan hal tersebut, dalam konteks Indonesia, pada pertengahan tahun 2006 muncul Surat Edaran Dirjen Bina Kesehatan Masyarakat tentang Larangan Medikalisasi Sunat Perempuan bagi Petugas Kesehatan. Atas dasar ini pulalah, Kementerian Negara Pemberdayaan Perempuan mengajukan surat ke MUI untuk meminta fatwa yang mengharapkan adanya larangan khitan terhadap perempuan ${ }^{7}$.

Artikel ini akan menjelaskan substansi dan argumentasi fatwa MUI seputar masalah khitan perempuan. Pembahasan diawali dengan deskripsi atas latar belakang fatwa, hasil kajian dan ketetapan fatwa, argumentasi yang dijadikan landasan, rekomendasi, dan diakhiri dengan penutup.

\section{Latar Belakang Fatwa}

Masalah khitan perempuan dibahas di MUI setelah memperoleh pertanyaan dari Kementerian Negara Pemberdayaan Perempuan. Pertanyaan tersebut muncul dengan disertai data penyimpangan pelaksanaan khitan perempuan di beberapa negara. Juga dikuatkan oleh penelitian yang dilakukan oleh Population Council terhadap pelaksanaan sunat perempuan di enam provinsi di Indonesia yang dibiayai oleh USAID dan Ford Foundation.

Bahkan, terkait dengan hal ini, Departemen Kesehatan Republik Indonesia Cq. Dirjen Bina Kesehatan Masyarakat telah mengeluarkan Surat Edaran tentang Larangan Medikalisasi Sunat Perempuan bagi Petugas Kesehatan.

${ }^{3}$ Sengaja penulis menyisipkan kata "penyimpangan", sebagaimana nanti dibahas tata cara khitan terhadap perempuan yang menekankan prinsip kehati-hatian, dan menghindari tindakan yang membahayakan. Hal ini mengingat praktik khitan terhadap perempuan sangat bervariasi.

${ }^{4}$ Dalam konteks lokal Indonesia, penelitian antara lain dilaksanakan oleh Population Council di enam provinsi di Indonesia dalam rentang waktu 2001-2003.

5 Namun, melihat hasil kajian terkait roadmap pelarangan medikalisasi sunat perempuan, ada kesan penelitian yang ada dilakukan justru untuk memperkuat keinginan untuk melarang sunat perempuan.

${ }^{6}$ Antara lain pada Sidang ke-39 Komite CEDAW Tahun 2007 di New York yang mendesak pelarangan pemotongan alat kelamin perempuan dalam peraturan perundang-undangan.

7 Permintaan fatwa ini mirip dengan beberapa elemen masyarakat yang meminta fatwa tentang pengharaman rokok beberapa waktu lalu. Permintaan fatwa dari masyarakat, lazimnya meminta keterangan tentang hukum sesuatu, bukan "memesan" hukum tertentu.
Di sisi lain, terjadi keragaman tata cara pelaksanaan khitan bagi perempuan, yang tidak jarang berimplikasi terhadap adanya dharar bagi perempuan. Dalam penelitian yang dilaksanakan di beberapa daerah di Indonesia pun telah terjadi keragaman praktik khitan perempuan, yakni ada yang dengan cara menggores dan mengerik, mencubit, menusuk, dan menindik serta insisi dan eksisi ${ }^{8}$.

WHO juga telah melakukan klasifikasi praktik sunat perempuan ke dalam empat tipe: (i) pemotongan "prepuce" dengan atau mengiris/menggores bagian atau seluruh klitoris; (ii) pemotongan klitoris dengan disertai pemotongan sebagian atau seluruh labia minora; (iii) pemotongan bagian atau seluruh alat kelamin luar disertai penjahitan atau penyempitan lubang vagina (infibulasi); dan (iv) tidak terklasifikasi, yakni: penusukan, pelubangan, pengirisan atau penggoresan terhadap klitoris dan/atau labia, pemotongan vagina, pemasukan bahan jamu yang bersifat korosif ke dalam vagina' ${ }^{9}$. Dorongan untuk pelarangan khitan perempuan semakin menguat dengan kampanye yang sistematis dari WHO serta beberapa lembaga donor.

Sementara itu, dalam literatur fikih tidak ditemukan satupun ulama mazhab fikih yang mu'tabar melarang praktik khitan perempuan. Bahkan, ada kesepakatan bahwa khitan perempuan adalah bentuk keutamaan. Hanya saja, terdapat perbedaan hukum fikihnya, antara sunah dan wajib ${ }^{10}$.

Untuk itu, penetapan fatwa tidak lagi seputar hukum khitan bagi perempuan. Karena secara fikih, ketentuan tersebut sudah sangat panjang lebar dijelaskan dalam pelbagai literatur, baik klasik maupun kontemporer. Permasalahan yang justru "baru" adalah adanya trend pelarangan terhadap khitan perempuan secara umum, bahkan sudah dituangkan dalam kebijakan pemerintahan, sekalipun itu hanya berbentuk surat edaran.

\section{Substansi dan Diktum Fatwa}

Diktum fatwa MUI tentang hukum pelarangan khitan terhadap perempuan terdiri atas empat bagian, yakni: status hukum khitan perempuan, hukum pelarangan khitan terhadap perempuan, batas atau cara khitan perempuan, dan rekomendasi. Diktum fatwa MUI selengkapnya adalah sebagai berikut:

\footnotetext{
${ }^{8}$ Laporan hasil penelitian Population Council tentang Pelaksanaan Sunat Perempuan di Indonesia (Studi di enam provinsi, 2001-2003).

9 Sebagaimana disebutkan dalam "Kebjakan Depkes dalam Menyikapi Praktik Sunat Perempuan", presentasi Dirjen Bina Kesehatan Masyarakat Departemen Kesehatan RI.

${ }^{10}$ Belakangan, ada beberapa ulama kontemporer, seperti Yûsuf alQaradhâwî, yang menambah ketetapan hukum "boleh", merujuk pada kenetralan pengertian yang diperoleh dari kata "makrûmah".
} 
Pertama, status hukum khitan perempuan. (1) Khitan, baik bagi laki-laki maupun perempuan, termasuk fitrah (aturan) dan syiar Islam. (2) Khitan terhadap perempuan adalah makrûmah, pelaksanaannya sebagai salah satu bentuk ibadah yang dianjurkan.

Kedua, hukum pelarangan khitan terhadap perempuan. Pelarangan khitan terhadap perempuan adalah bertentangan dengan ketentuan syariah karena khitan, baik bagi laki-laki maupun perempuan, termasuk fitrah (aturan) dan syiar Islam.

Ketiga, batas atau cara khitan perempuan. Dalam pelaksanaannya, khitan terhadap perempuan harus memperhatikan hal-hal sebagai berikut: (1) Khitan perempuan dilakukan cukup dengan hanya menghilangkan selaput (jaldah/colum/praeputium) yang menutupi klitoris; (2) Khitan perempuan tidak boleh dilakukan secara berlebihan, seperti memotong atau melukai klitoris (insisi dan eksisi) yang mengakibatkan dharar.

Keempat, rekomendasi. Pertama, meminta kepada Pemerintah cq. Departemen Kesehatan untuk menjadikan fatwa ini sebagai acuan dalam penetapan peraturan/regulasi tentang masalah khitan perempuan. Kedua, menganjurkan kepada Pemerintah cq. Departemen Kesehatan untuk memberikan penyuluhan dan pelatihan kepada tenaga medis untuk melakukan khitan perempuan sesuai dengan ketentuan fatwa ini.

Dari diktum fatwa tersebut, sejatinya fatwa MUI ini ingin menegaskan dua substansi. Pertama, menegasikan tindak pelarangan khitan terhadap perempuan. Kedua, menegaskan tata cara berkhitan bagi perempuan yang sesuai dengan ketentuan syariah dan melarang tindakan berlebihan dalam praktik khitan yang menimbulkan bahaya bagi perempuan, baik secara fisik maupun psikis.

\section{Argumentasi atas Penetapan Fatwa}

Fatwa MUI terkait dengan masalah ini, diawali dengan adanya penegasan bahwa khitan, baik bagi lakilaki maupun perempuan, termasuk fitrah (aturan) dan syiar Islam. Pelaksanaannya bagian dari ibadah.

Hal ini menjadi penting untuk ditegaskan terkait dengan adanya kesalahpahaman terhadap posisi khitan. Khitan tidak hanya sekadar kebutuhan medis, namun merupakan bentuk ibadah yang "dogmatik". Meski tidak jarang ajaran agama yang bersifat dogmatik tersebut melahirkan hikmah positif. Sekalipun secara medis tidak (atau lebih tepatnya belum) ditemukan manfaat terhadap pelaksanaan khitan bukan serta-merta ia menjadi terlarang. Hal ini sangat berbeda dengan cara pandang medik semata. Cara pandang yang seperti ini dipastikan akan melarang khitan jika tidak ada pertimbangan medis. Selanjutnya, secara lebih ekstrem, cara pandang seperti ini akan mengabsahkan gerakan prointegrasi genital yang juga melarang khitan laki-laki sebagaimana larangan khitan terhadap perempuan di $\mathrm{AS}^{11}$.

Dalam teori hukum Islam, ibadah itu ada yang berdimensi rasional (ta'aqqulî/ma'qûlât al-ma'nâa) dan ada yang dogmatik (ta'abbudîlghayr ma'qûlât al-ma'nâ). Nah, khitan sekalipun tidak dapat dinalar sesuai dengan nalar medik sekalipun, ia tetap dan harus eksis sebagai bentuk "identitas" agama ${ }^{12}$.

Penetapan fatwa bahwa pelarangan khitan terhadap perempuan adalah bertentangan dengan syariah, didasarkan pada keumuman ayat Alquran, Sunah, dan pandangan ulama mazhab yang bersepakat atas kebolehan khitan terhadap perempuan. Secara tersirat, terdapat adanya konsensus di kalangan ulama mengenai ketidakbenaran tindakan pelarangan khitan terhadap perempuan. Ulama sepakat bahwa khitan terhadap perempuan tidak haram, juga tidak makruh.

Dalil dari Alquran yang dijadikan landasan fatwa MUI ini adalah keumuman ayat tentang keharusan mengikuti millah Ibrahim, antara lain dalam surah alNahl [16] ayat $123^{13}$ :

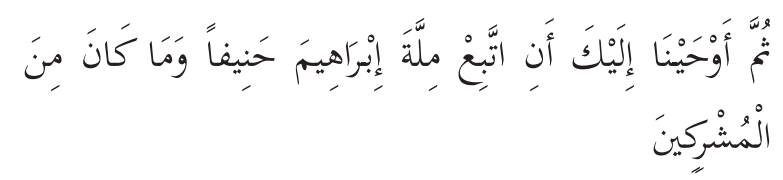

Kemudian Kami wahyukan kepadamu (Muhammad), "Ikutilah agama Ibrahim seorang yang hanif" dan bukanlah dia termasuk orang-orang yang mempersekutukan Tuhan. (Q.s. al-Nahl [16]: 123)

Dalam Tafsir al-Shan'anî disebutkan, cakupan "al-binâfyyyah" antara lain: tauhid, khitan, larangan menikah dengan ibu kandung, anak kandung, dan saudara kandung. ${ }^{14}$

Di samping itu, al-Syawkânî menjelaskan pengertian "millab" di sini antara lain mencakup seluruh hal yang disyariatkan oleh Allah melalui nabi-Nya. Sedangkan cakupan millah yang diperintahkan untuk diikuti dalam ayat ini, ada yang melihatnya sebatas masalahmasalah ushûl. Sementara al-Syawkânî lebih memilih pengertian millah yang menyatakan seluruh ketentuan

\footnotetext{
${ }^{11}$ Sebagaimana liputan dalam rubrik khusus dengan judul "Tentang Sunat dan Khitan" yang dimuat dalam Warta Kota pada Minggu, 5 April 2009.

${ }^{12}$ Dalam pelbagai literatur, disebutkan khitan sebagai fitrah dan "min sya'air al-Islâm", suatu identitas keagamaan yang khas dan unik.

${ }_{13}$ Di samping itu, fatwa ini juga mendasarkan pada keumuman ayat tentang perintah mengikuti millah Ibrahim sebagaimana dalam surah Âli 'Imrân[3]: 95, dan al-Nisâ'[4]:125 serta keumuman tunduk terhadap perintah Allah sebagaimana dalam surah Âli 'Imrân[3]: 31.

${ }^{14}$ Tafsir al-Shan'anî, Juz I, h. 60.
} 
syariah sepanjang tidak di-nasakh ${ }^{15}$, termasuk ibadah haji dan khitan.

Ayat ini juga disebutkan secara eksplisit oleh Imam Nawawî dalam Majmûn ${ }^{\prime \prime}$ sebagai landasan kewajiban khitan dan juga al-Syawkânî dalam Nayl al-Authâr ${ }^{17}$ sebagai landasan pensyariatan khitan. Hal ini sekaligus menjawab analisis Ahmad Luthfi Fathullah yang menegaskan jarang ulama yang menggunakan ayat tersebut sebagai dalil wajibnya khitan ${ }^{18}$.

Dalam perspektif ilmu tafsir, dikenal dengan tafsir ayat dengan ayat, atau dengan Hadis, yang dikenal dengan tafsir bi al-ma'tsur. Nah, dalam konteks ayat ini, ada penjelasan dari Hadis shahlîh yang diriwayatkan oleh Imam al-Bukhârî dan Muslim dengan redaksi:

$$
\text { ختن إبراهيم وهو ابن ثمانين سنة بالقدوم }
$$

"Nabi Ibrahim saw berkhitan pada usia delapan puluh tahun dengan menggunakan kapak" (H.r. al-Bukhârî dan Muslim).

Dalam kaidah usul fikih, keumuman suatu lafaz tetap berlaku umum sepanjang tidak ada yang mentakhshîsh. Bahkan, Imam Syâfi'î menegaskan petunjuk (dalâlah) lafaz yang umum bersifat qath'i.

Di samping keumuman ayat di atas, fatwa MUI ini juga didasarkan pada beberapa Hadis Nabi Saw., di antaranya Hadis shahîh $\underline{\underline{h}}$ yang diriwayatkan para punggawa Hadis kenamaan, dengan redaksi sebagai berikut:

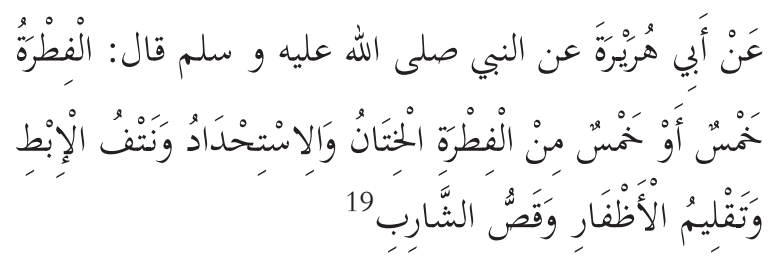

Lima perkara yang merupakan fitrah manusia: khitan, al-Istihdâd (mencukur rambut pada sekitar kemaluan), mencukur bulu ketiak, menggunting kuku dan memotong kumis. (H.r. Jamâah dari Abû Hurayrah R.a.).

${ }^{15}$ Lihat al-Syawkânî, Fath al-Qâdir, (Bayrût: Dâr al-Fikr, t.th), Juz III, h. 203

${ }^{16}$ Imam Nawawî, al-Majmû̀, (Bayrût: Dâr al-Fikr, 1996), Juz I, h. 365 .

${ }^{17}$ Al-Syauwkânî, Nayl al-Awthâr, (Bayrût: Dâr al-Jail, 1973), Juz I, h. 139 .

${ }^{18}$ Lihat Ahmad Luthfi Fathullah dalam presentasinya mengenai "Fikih Khitan Perempuan".

${ }^{19}$ Hadis ini termuat dalam Shahîh al-Bukhârî, Juz V, h. 2209, Hadis nomor 5550, Shah hîh Muslim, Juz I h. 221, Hadis nomor 257, Shabîh ibn Hibbân, Juz XII, h. 291 Hadis nomor 5479 dan halaman 293, Hadis nomor 5482, Sunan al-Turmudzî, Juz V, h. 91, Sunan alBayhaqî al-Kubrâ, Juz I, h. 149, Sunan Abî Dâwud Juz IV, h. 84, Sunan al-Nasai, juz I h. 14 dan 15 serta juz VIII h. 128 dan 129, Sunan Ibn Majah Juz I h. 107, al-Muwaththa, Juz II, h. 921, Musnad A $\underline{\text { hmad, Juz }}$ II, h. 229, 239, 283, 410, dan 489 serta masih ada lagi sejumlah 59 kitab yang memuat Hadis ini.
Dari sisi kualitas Hadis, tidak ada yang meragukan darajat kesahihannya. Namun, terjadi perbedaan terkait dengan kandungan hukum yang di-istinbath-kan dari redaksi Hadis di atas ${ }^{20}$.

Di samping Hadis di atas, ada Hadis Shahîh $\underline{h}$ lain yang dijadikan landasan tentang masalah eksistensi khitan

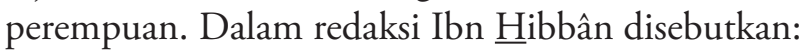

$$
\text { عن عائشة قالت قال رسول الله صلى الله عليه وسلم : }
$$

Dari 'Â'isyah Ra. ia berkata, "Rasulullah Saw. bersabda, "Apabila bertemu dua khitan maka wajiblah mandi".

Sedangkan redaksi dalam Sunan Ibn Mâjah sebagai berikut:

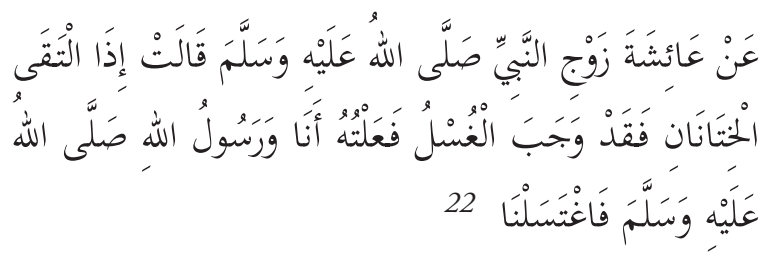

Dari 'Â'isyah, istri Rasulullah Saw., ia berkata, "Apabila bertemu dua khitan maka wajiblah mandi, aku dan Rasulullah telah melakukannya, lalu kami mandi."

Dari sisi kualitas, Hadis ini juga tidak diperselisihkan keabsahannya. Petunjuk dari Hadis ini secara jelas menetapkan eksistensi khitan, baik laki-laki maupun perempuan, terlepas adanya perbedaan penetapan hukumnya, antara wajib dan sunah.

Secara lebih teknis, fatwa ini juga memuat beberapa Hadis yang terperinci terkait khitan perempuan, meski dengan kualitas Hadis yang lemah, ada yang mengategorikan sebagai $d h a$ îf , dan ada yang mengatakan sebagai hasan.

Melengkapi argumentasi fatwanya, MUI menegaskan adanya konsensus (ijmak) ulama yang menegaskan bahwa khitan perempuan adalah hal yang disyariatkan dan tidak ada satupun yang melarangnya. Dari keumuman ayat Alquran dan Hadis yang shahbîh, praktik sahabat, serta literatur khazanah klasik, tidak ditemukan satu pandanganpun yang menyatakan adanya larangan khitan terhadap perempuan, baik yang dalam status hukum makrûh, apalagi haram. Bahkan, ada penegasan tentang telah terjadinya khitan perempuan di zaman

${ }^{20}$ Namun, dalam teori usul fikih sepanjang tidak ada indikasi pengertian yang spesifik, maka hukum yang dituju pengertian teks tetap merujuk pada pengertian umumnya.

${ }^{21}$ Lihat Shahîh $\underline{\text { Ibn }}$ Hibbân, (Bayrût: Mu'assasah al-Risâlah, 1993), Cet. II, Juz III, h. 456.

${ }^{22}$ Sunan Ibn Mâjah, (Bayrût: Dâr al-Fikr, t.th), Juz I, h. 199, Hadis no. 608. Hadis dengan substansi yang sama juga diriwayatkan dalam Shahîh al-Bukhârî, Juz I, h. 110; Sunan al-Turmudzî, Juz I, h. 180 dan 182; al-Sunan al-Kubra, Juz I, h. 108; al-Muwaththa, Juz I, h. 45; Musnad Ahmad, Juz VI, h. 123, serta lebih dari 70 kali pengulangan dalam pelbagai kitab yang berhasil penulis teliti. 
Nabi Saw., dan tidak ada pengingkaran atasnya.

Pendapat ini juga ditegaskan oleh Yûsuf alQaradhawi dalam al- $\underline{H} u k m$ al-Syar'i fî Khitân al-Inâts dengan redaksi:

$$
\begin{aligned}
& \text { والخلاصة: أن أحدا من الفقهاء لم يقّل: إنه حرام أو مكروه } \\
& \text { تحريما أو تنزيها. وهذا يدل على المشروعية والجواز في الجملة }
\end{aligned}
$$

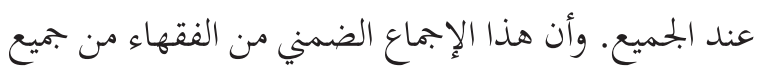

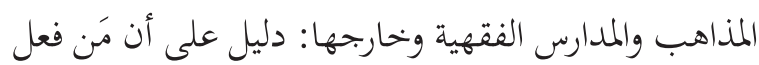

$$
\begin{aligned}
& \text { هذا الختان، على ما جاء به الحلديث، (الذي حسَّنه قوم } \\
& \text { وضعَّفه آخرون)، الذي نصح الخاتنة بالإشمام وعدم النَّهك مُك } \\
& \text { والإسراف: لا جُناح عليه، ولم يقترف عملا محرَّما }
\end{aligned}
$$

Ringkasnya tidak ada satupun ahli fikih yang menyatakan khitan perempuan itu haram atau makrûh, baik tahrîm maupun tanzîh. Ini merupakan dalil atas pensyariatan dan kebolehan khitan perempuan. Ijma dhimnî dari seluruh fukaha ini merupakan dalil bahwa orang yang melakukan khitan perempuan, sepanjang sejalan dengan ketentuan Hadis (ada yang menyatakan hasan dan sebagian $\left.d h a^{\wedge} \hat{\imath}\right)$, di mana Nabi menyarankan memotong sedikit dan tidak berlebihan, maka jelas bukan perbuatan dosa, juga bukan sebagai tindak kriminal.

Juga ditegaskan oleh Syaikh al-Azhar, Jad al- $\underline{\text { Haqq, }}$ dalam Buhîust wa Fatâwâ Islâmiyyah fì Qhadhâyâ Mu'ashshirah, yang menulis:

$$
\begin{aligned}
& \text { اتفقت كلمة فقهاء المذاهب على أن الختان للرجال والنساء }
\end{aligned}
$$

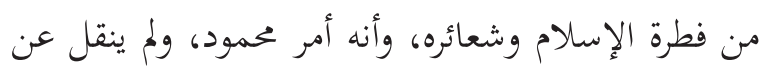



$$
\begin{aligned}
& \text { أيدينا - قول يمنع الختان للرجال أو النساء"، أو عدم جوازه }
\end{aligned}
$$

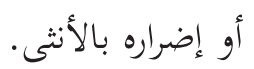

Seluruh mazhab dalam fikih sepakat bahwa sesungguhnya khitan bagi laki-laki dan perempuan adalah bagian dari fitrah dan syiar Islam. Khitan pada dasarnya adalah perkara terpuji, dan sepanjang penelaahan kami atas kitab-kitab fikih, tidak ada satupun ahli fikih yang melansir sebuah pendapat yang melarang khitan bagi laki-laki dan perempuan, atau pendapat yang melarang atau menganggap adanya bahaya (dharar) khitan bagi perempuan.

\begin{tabular}{|c|c|c|c|}
\hline \multirow[b]{2}{*}{ Mazhab } & \multicolumn{2}{|c|}{ Hukum Khitan } & \multirow[b]{2}{*}{ Keterangan } \\
\hline & $\begin{array}{c}\text { Laki- } \\
\text { Laki }\end{array}$ & $\begin{array}{c}\text { Perem } \\
\text { puan }\end{array}$ & \\
\hline Hanafiyyah & Sunah & Sunah & \\
\hline Mâlikiyyah & Wajib & Sunah & $\begin{array}{l}\text { Sebagian ulama } \\
\text { Mâlikiyyah menegaskan } \\
\text { keduanya wajib, sebagian } \\
\text { kecil menganggap } \\
\text { keduanya sunah. }\end{array}$ \\
\hline Syâfi'iyyah & Wajib & Wajib & \\
\hline$\underline{\text { Hanabilah }}$ & Wajib & Sunah & $\begin{array}{l}\text { Sebagian ulama } \\
\text { Hanabilah menegaskan } \\
\text { keduanya wajib, sebagian } \\
\text { lain dalam satu riwayat } \\
\text { menganggap keduanya } \\
\text { sunah }\end{array}$ \\
\hline Zhahiriyyah & Wajib & $\begin{array}{l}\text { Makrû̀ } \\
\text { mah }\end{array}$ & \\
\hline
\end{tabular}

Hanya saja, perbedaan terjadi pada apakah ia sunah atau wajib. Secara sederhana, pandangan ulama tersebut dapat dilihat dalam tabel berikut ini:
Tabel Pendapat Mazhab Fikih tentang Hukum Khitan ${ }^{23}$

Dari sini tampak jelas bahwa tidak satupun pandangan ulama yang melarang khitan perempuan. Belakangan muncul upaya menetralkan pengertian kata "makrûmah" sebagai sekadar kebolehan, yang berfungsi sebagai irsyâd (bimbingan). Walau demikian, pengertian tersebut tetap menegasikan tindak pelarangan terhadap khitan perempuan.

Argumentasi fiqhiyyah terkait dengan perbedaan pandangan ulama mengenai status hukum khitan perempuan sengaja tidak dielaborasi secara rinci dalam artikel ini, mengingat inti masalahnya adalah pada tindakan pelarangan terhadap khitan perempuan. Inti masalah tersebut sudah terjawab dengan deskripsi pandangan fukaha klasik mengenai hukum khitan perempuan, dengan temuan utama bahwa seluruh fukaha menetapkan eksistensi khitan perempuan, dan tidak ada satupun yang menegasikannya, terlebih menganggapkan sebagai kriminal.

\section{Moderasi Antara Dua Ekstrem}

Dari paparan di atas, penulis menilai bahwa ketetapan fatwa MUI terkait dengan masalah khitan perempuan merupakan langkah moderasi di antara dua ekstrem. Jika digambarkan secara sederhana, penyikapan terhadap masalah khitan perempuan, terdapat dua

${ }^{23}$ Tabel ini didasarkan pada penelitian atas pelbagai literatur fikih klasik yang "mu'tabar", antara lain dalam I'ânah al-Thâlibîn, (Bayrût: Dâr al-Fikr, t.th), Juz IV, h. 174); Hawâsyî al-Syarwanî, (Bayrût: Dâr al-Fikr, t.th), Juz I, h. 142; Mughni al-Muhtâj, (Bayrût: Dâr al-Fikr, t.th), Juz IV, h. 202); Minhâj al-Thâlibîn, (Bayrût: Dâr al-Ma'rifah, t.th), Juz I, h. 136; al-Bahr al-Raiq, (Bayrût: Dâr al-Ma'rifah, t.th), Juz I, h. 61; Fath al-Bâri, (Bayrût: Dâr al-Ma>rifah, t.th), Juz I, h. 340 dan 347; 'Awn al-Ma'bûd, (Bayrût: Dâr al-Kutub al-'Ilmiyyah, Juz XIV, h. 123; Nayl al-Awthâr, (Bayrût: Dâr al-Jail, t.th), Juz I, h. 137; Kutub wa Rasẩil wa Fatâwâ Ibn Taymiyyah fi al-Fiqh, (Maktabah Ibn Taymiyyah, t.th), Juz XXI, h. 114; dan Tuhfah al-A $\underline{h} w a d z \hat{i}$, (Bayrût: Dâr al-Kutub al-Ilmiyyah, t..th), Juz VIII, h. 28. 
kutub yang berlawanan.

Pertama, pihak yang melakukan khitan terhadap perempuan dengan praktik yang secara pasti membahayakan, seperti dengan menjepit dan sejenisnya, menutup dan menjahit vagina, mengambil seluruh klitoris dan labia baik mayora maupun minora, dan praktik lain yang membahayakan, sebagaimana digambarkan terjadi di beberapa negara Afrika Utara. ${ }^{24}$

Kedua, pihak yang melarang seluruh praktik khitan perempuan, dengan alasan sebagai bentuk tindak kekerasan, mutilasi, dan pelanggaran hak asasi manusia ${ }^{25}$. Banyak tulisan yang bernada sangat provokatif dan memaksakan opini bahwa khitan perempuan adalah tindakan kriminal yang harus diberangus. Bahkan, tanpa disadari juga dilakukan oleh beberapa dokter serta petugas medis sendiri ${ }^{26}$. Lebih ironis lagi, Surat Edaran Dirjen Bina Kesehatan Masyarakat Departemen Kesehatan, yang ditandatangani Sri Astuti Suparmanto, juga mengklaim bahwa sunat perempuan sebagai penyebab perusakan alat kelamin perempuan ${ }^{27}$, tanpa ada penjelasan mengenai khitan yang seperti apa yang masuk kategori merusak itu.

Fatwa MUI berdiri di antara dua ekstrem tersebut, karena keduanya, secara akademik maupun keagamaan bertentangan dengan ketentuan normatif yang

\footnotetext{
${ }^{24}$ Jurnalis Uddin menjelaskan setidaknya ada enam model yang beragam dalam praktik khitan perempuan yaitu: (1) hanya menusuk dengan jarum suntik pada pada preputium clitoridis, ini kebanyakan di Indonesia; (2) mengambil sebagian atau seluruh preputium clitoridis, sehingga clitoris ter-expose (alasan medis agar perempuan bisa terangsang sehingga mudah orgasme); (3) memotong sebagian clitoris, (umumnya di Mesir dan negara-negara Timur Tengah); (4) memotong seluruh clitoris (di negara-negara Afrika sebelah utara garis khatulistiwa); (5) mengambil seluruh clitoris dan labia minora; dan (6) mengambil seluruh clitoris, seluruh labia minora dan seluruh labia majora (infibulation=pharaotic excision=female genital mutilation or FGM) (dilakukan di negara-negara Afrika utara khatulistiwa).

${ }^{25}$ Sebagaimana kampanye yang dilakukan oleh pegiat larangan khitan terhadap perempuan yang memaksakan untuk memasukkan tindakan khitan perempuan sebagai "praktik perusakan alat kelamin". Anehnya, pertimbangan ini pulalah yang dijadikan alasan nomor satu dalam Surat Edaran tentang Larangan Medikalisasi Sunat Perempuan bagi Petugas Kesehatan yang ditandatangani oleh Dirjen Bina Kesehatan Masyarakat Depkes pada 20 April 2006.

${ }_{26}$ Sebagaimana ditulis oleh dokter Rachmat Sentika dari Ikatan Dokter Anak Indonesia (IDAI) dalam presentasinya yang tendensius dan stigmatik, dengan menulis "Telah terjadi perusakan alat kelamin perempuan karena praktik sunat perempuan". Lihat, Rachmat Sentika, "Larangan Melakukan Sunat Bagi Perempuan", makalah presentasi yang ditulis tahun 2006, tidak diterbitkan. Sementara di bagian lain Rachmat Sentika secara stereotipikal menuliskan, "Di Afrika dan Timur Tengah dikenal sebagai alat untuk mengkebiri perempuan dan umumnya karena laki-laki biasanya mempunyai kecenderungan untuk poligami, dan mencari perempuan untuk kepuasaan seksualnya". Menghubungkan tindakan poligami dengan khitan perempuan adalah hal yang sangat gegabah.

27 Lihat Surat Edaran tentang Larangan Medikalisasi Sunat Perempuan bagi Petugas Kesehatan yang ditandatangani oleh Dirjen Bina Kesehatan Masyarakat Depkes pada 20 April 2006.
}

dikembangkan oleh Islam.

Terhadap pihak yang menyatakan pelarangan mutlak terhadap khitan perempuan, secara agama jelas bertentangan. Untuk itu, salah satu diktum fatwa MUI menegaskan bahwa "pelarangan khitan terhadap perempuan adalah bertentangan dengan ketentuan syariah karena khitan, baik bagi laki-laki maupun perempuan, termasuk fitrah (aturan) dan syiar Islam". Sebelumnya, fatwa ini menjelaskan bahwa pelaksanaan khitan, baik bagi laki-laki maupun perempuan, termasuk fitrah (aturan) dan syiar Islam.

Walau demikian, fatwa MUI tidak menutup mata terhadap fakta adanya pelbagai praktik khitan perempuan yang menimbulkan bahaya. Untuk itu, guna menghindari adanya bahaya akibat penyimpangan terhadap praktik khitan perempuan, fatwa MUI juga menegaskan mengenai batasan atau tata cara khitan perempuan sesuai dengan ketentuan syariah. Pertama, khitan perempuan dilakukan cukup dengan hanya menghilangkan selaput (jaldah/colum/praeputium) yang menutupi klitoris. Kedua, khitan perempuan tidak boleh dilakukan secara berlebihan, seperti memotong atau melukai klitoris (insisi dan eksisi) yang mengakibatkan dharar.

Penentuan batasan atau tata cara khitan tersebut didasarkan pada petunjuk yang diberikan Nabi Saw., yang menekankan prinsip: sedikit saja, tidak berlebihan, dan tidak menimbulkan bahaya. Dalam keterangan dalam Hadisnya, Rasulullah Saw. hanya memperbolehkan pemotongan itu dilakukan dengan syarat tidak berlebihan, sehingga tidak menyebabkan bahaya, seperti mengurangi fungsi seksual dan dampak fisikis lainnya ${ }^{28}$. Dalam elaborasi lebih lajut, para ulama memberikan penjelasan lebih detil. ${ }^{29}$

Di samping itu, penetapan batas atau tata cara khitan ini juga merujuk pada pendapat beberapa ahli kedokteran, di antaranya kesimpulan dalam presentasi Jurnalis Uddin (Fakultas Kedokteran Universitas YARSI Jakarta) yang menegaskan bahwa khitan pada laki-laki hanya memotong preputium penis, mestinya yang dilakukan pada khitan perempuan adalah juga hanya memotong preputium clitoridis saja ${ }^{30}$. Hal

${ }^{28}$ Sebagaimana juga disimpulkan oleh Ahmad Luthfi Fathullah dalam presentasinya mengenai "Fiqh Khitan Perempuan" ketika menjelaskan tentang cara khitan perempuan.

${ }^{29}$ Dalam penelitian yang dilakukan oleh penulis, terdapat lebih dari 13 literatur klasik yang menerangkan tata cara khitan perempuan, yang intinya adalah dengan "memotong sedikit selaput yang menempel di atas farji (vagina) yang berbentuk mirip cengger ayam jantan, yang berada di atas lobang kencing". Lihat, antara lain: Fath al-Mu'in, karya Zayn al-Dîn al-Malaybarî, (Bayrût: Dâr al-Fikr, t.th), Juz IV, h. 174; Mughni al-Muhtâj, Muhammad al-Khâtib al-Syarbinî, (Bayrût: Dâr alFikr, t.th), Juz IV, h. 202.

${ }^{30}$ Lihat Jurnalis Uddin, "Sirkumsisi (Khitan) pada Perempuan", 
yang sama juga disebutkan oleh Alfibein (Fakultas Kedokteran Universitas Indonesia) dan Nanang Miftah Fajri (Fakultas Kedokteran Universitas Brawijaya Malang), sebagai hasil konsultasi MUI dengan ahli yang independen.

Dengan demikian, khitan terhadap perempuan secara umum sebanding dengan khitan terhadap lakilaki. Hanya saja, karena secara anatomis antara keduanya berbeda, maka tata caranya juga berbeda. Khitan lakilaki dilakukan dengan membuang kulup yang menutupi penis (hasyafah), sedang pada perempuan dilakukan dengan membuang "kulup" yang menutupi klitoris $(b i z h r)^{31}$.

Nah, fakta terhadap adanya pelbagai dampak negatif yang ditemukan lebih sebagai akibat dari penyimpangan dari praktik khitan perempuan tersebut. Untuk itu, sebagai tindak lanjut dari langkah moderat dalam penyikapan terhadap masalah khitan perempuan, fatwa MUI diakhiri dengan dua poin rekomendasi. Pertama, meminta kepada Pemerintah cq. Departemen Kesehatan untuk menjadikan fatwa ini sebagai acuan dalam penetapan peraturan/regulasi tentang masalah khitan perempuan. Kedua, menganjurkan kepada Pemerintah cq. Departemen Kesehatan untuk memberikan penyuluhan dan pelatihan kepada tenaga medis untuk melakukan khitan perempuan sesuai dengan ketentuan fatwa ini.

Kedua rekomendasi tersebut diberikan mengingat masalah khitan perempuan, sebagai sebuah bentuk ibadah, dalam diskursus hukum Islam termasuk dalam masalah fiqh ijtimâ' $\hat{\imath}$, yang punya dimensi sosial, sehingga membutuhkan "intervensi" dari pemegang kebijakan publik. Namun, mandat tersebut diberikan untuk kepentingan pemberian petunjuk pelaksanaan, fasilitasi, dan deseminasi kebijakan mengenai tata cara khitan yang sejalan dengan ketentuan syariah sekaligus standar medis. Sedangkan langkah pelarangan khitan terhadap perempuan merupakan tindakan melampaui "mandat" tersebut.

\section{Perlindungan Terhadap Hak Perempuan}

Dalam paparan di atas, dapat dipahami bahwa Fatwa MUI tentang khitan perempuan sejalan dengan upaya perlindunganterhadaphakperempuan. Pemberian penjelasan mengenai batasan yang diperhatikan dalam pelaksanaan khitan justru meneguhkan perlindungan terhadap hak perempuan, yakni perlindungan dari dampak negatif yang ditimbulkan akibat tindakan

makalah presentasi pada September 2006, tidak diterbitkan.

${ }^{31}$ Hal yang sama juga dijelaskan oleh dokter Fathiyyah Hasan dalam kertas kerjanya, "Táshil Khitân al-Untsâ". berlebihan dalam praktik khitan yang menyebabkan bahaya.

Setelah adanya ketegasan dan kejelasan posisi khitan terhadap perempuan, serta ketidakabsahan pelarangan khitan terhadap perempuan, masih saja muncul opini sistematis bahwa khitan perempuan merupakan pelanggaran terhadap hak perempuan, merusak alat reproduksi, dan opini stereotipikal lainnya. Apakah khitan perempuan merupakan pengingkaran terhadap hak-hak perempuan yang dijunjung tinggi, terkait perlindungan akan kesehatan dan hak reproduksi mereka. Bahkan dikategorikan sebagai tindakan kriminal?

Untuk menjawabnya, perlu ada verifikasi kelompok masyarakat yang melakukan gerakan pelarangan khitan terhadap perempuan.

Secara umum, berdasarkan alasan dan latar belakang pelarangan khitan terhadap perempuan, dapat dikategorikan menjadi dua, yakni gerakan pelarangan khitan perempuan yang menyimpang dan pelarangan khitan perempuan secara mutlak.

Pertama, kelompok yang melarang khitan perempuan yang menyimpang dari kaidah agama dan medis. Kelompok ini mengadvokasi atas peyimpangan pelaksanaan khitan terhadap perempuan. Mereka mendasarkan pelarangan khitan perempuan pada realitas adanya penyimpangan terhadap praktik khitan perempuan, dan tidak sesuai dengan ketentuan fikih. Sejatinya, yang dituntut adalah pelarangan khitan perempuan yang menyimpang dari ketentuan, yang mengakibatkan bahaya.

Agaknya, pandangan kelompok ini sejalan dengan ketentuan fatwa MUI. Bahwa tindakan khitan yang tidak sesuai dengan ketentuan syariah dan membahayakan harus dilarang. Sementara, khitan perempuan yang sejalan dengan ketentuan syariah tidak terlarang, bahkan dianjurkan sebagai fitrah dan syiar Islam.

Ketentuan mengenai tata cara khitan terhadap perempuan yang dijelaskan dalam diktum fatwa MUI menegaskan batasan-batasan, yang secara fikih dibenarkan dan secara medis tidak menimbulkan bahaya. Jika terdapat penyimpangan, yang mengakibatkan bahaya secara nyata bagi si perempuan, maka ia secara otomatis terlarang, dan bahkan bisa dihukumi haram. Sebagaimana sabda Nabi Saw.:

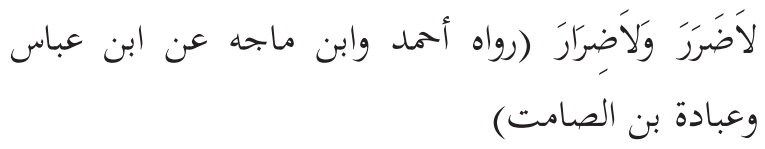

Tidak boleh membahayakan diri sendiri dan tidak boleh (pula) membahayakan orang lain.

Pada kelompok ini, hendaknya kampanye diarahkan 
pada pemberian pemahaman yang benar mengenai tata cara khitan terhadap perempuan yang benar secara syariah dan aman secara medis. Dengan demikian, fatwa MUI dapat dijadikan guidence serta bahan efektif untuk deseminasi kebijakan ini.

Kedua, kelompok yang melarang khitan perempuan secara mutlak. Kelompok ini umumnya mendasarkan larangannya pada dalil umum tentang upaya penghapusan segala bentuk diskriminasi terhadap perempuan (sebagaimana diatur dalam UU Nomor 7 Tahun 1984 tentang Pengesahan Konvensi Mengenai Penghapusan Segala Bentuk Distribusi Terhadap Wanita).

Isu pelarangan khitan perempuan menjadi polemik dan muncul menjadi isu publik yang kontroversial seiring dengan adanya kampanye sistemik, yang mengaitkan praktik khitan perempuan dengan isu perlindungan hak asasi manusia, hak anak, dan juga hak perempuan dalam melakukan reproduksi.

Secara normatif, gagasan dan semangat perlindungan hak asasi manusia, termasuk hak anak dan hak perempuan menjadi komitmen semua bangsa yang berbudaya, apapun agamanya.

Permasalahan muncul ketika mengategorikan khitan sebagai bentuk pelanggaran HAM. Hal ini mengingat, dalam tataran implementasi, penentuan suatu perbuatan dikategorikan sebagai pelanggaran atau tidak sifatnya sangat subyektif, sangat kondisional dan juga sangat terkait dengan struktur sosial, keyakinan, dan nilai yang hidup di masyarakat.

Ada upaya sistematis menggiring opini bahwa pelaksanaan khitan terhadap perempuan adalah tindakan kriminal, perusakan alat kelamin, tindak mutilasi, dan pelanggaran hak asasi manusia ${ }^{32}$. Menurut hemat penulis, kelompok ini sangat bias budaya dan

${ }^{32}$ Antara lain terlihat dalam Fransiska Lisnawati Kerong, Female Genital Mutilation Ditinjau dari Aspek Hukum Perlindungan Perempuan dan Hak Asasi Manusia, (Jakarta: Fakultas Hukum UNIKA Atmajaya, 2008), sebagaimana diunduh dalam situs perpustakaan Fakultas Hukum Universitas Katolik Atmajaya. Dalam abstraknya ia menulis, "Pelaksanaan Female Genital Mutilation merupakan pelanggaran terhadap hak asasi perempuan, di mana hak asasi perempuan adalah sama dengan hak asasi manusia. Hak perempuan atas kesehatan alat reproduksi dan kehidupan seksual telah dilanggar dengan dilakukannya mutilasi tersebut". Juga artikel yang ditulis oleh Yuli Indarti, "Khitan Perempuan Pelanggaran Hak Azasi Manusia yang Diabaikan". Dalam artikel tersebut ia menulis, "Mengingat khitan perempuan merupakan tindakan melukai, memotong organ seksual tanpa indikasi medis dan biasanya berbahaya secara fisik dan psikologis tentunya praktik tersebut akan bertentangan dengan hak-hak atas kesehatan reproduksi tersebut. Pelaksanaan khitan juga tanpa seizin yang empunya tubuh sehingga dalam hal ini yang bersangkutan tidak punya hak penghargaan atas integritas tubuhnya dan efek permanen berupa pengurangan kenikmatan seksual juga merupakan pelanggaran hak-hak seksualnya". Logika ini jelas bertentangan dengan prinsip hukum Islam, yang menegaskan bahwa prinsip asal pelaksanaan ibadah adalah ta'abbudî (dogmatik). juga agama.

Bahwa CEDAW (Convention on The Elimination of All forms of Discrimination Againts Women) sebagai sebuah konvensi internasional yang sudah diratifikasi ke dalam UU, kita memang terikat sepanjang hal itu tidak bertentangan dengan tata kehidupan masyarakat yang meliputi nilai-nilai budaya, adat istiadat, serta norma-norma keagamaan yang masih berlaku. Dalam fikih perikatan, etika ini sangat dijaga. Hadis di bawah ini menegaskan komitmen itu:

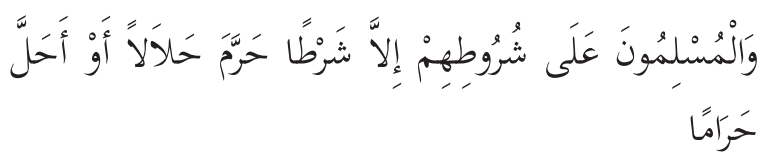

Kaum muslimin terikat dengan syarat-syarat mereka kecuali syarat yang mengharamkan yang halal atau menghalalkan yang haram.

Namun, dalam implementasinya sangat tergantung dengan pelbagai aspek, baik hukum, budaya, agama, dan tradisi yang hidup di masyarakat. Pemaksaan pemaknaan khitan perempuan sebagai bentuk pelanggaran adalah tindakan inkonstitusional, provokatif, dan justru bertentangan dengan ketentuan UU Nomor 7 Tahun 1984 tentang Pengesahan Konvensi Mengenai Penghapusan Segala bentuk Diskriminasi terhadap Wanita (CEDAW).

UU tersebut secara eksplisit menegaskan bahwa pelaksanaan ketentuan dalam Konvensi ini wajib disesuaikan dengan tata kehidupan masyarakat yang meliputi nilai-nilai budaya, adat istiadat serta normanorma keagamaan yang masih berlaku dan diikuti secara luas oleh masyarakat Indonesia. Pancasila sebagai pandangan hidup bangsa dan Undang-Undang Dasar 1945 sebagai sumber hukum nasional memberikan keyakinan dan jaminan bahwa pelaksanaan ketentuan Konvensi ini sejalan dengan tata kehidupan yang dikehendaki bangsa Indonesia ${ }^{33}$. Dan salah satu norma keagamaan yang masih berlaku dan diikuti secara luas oleh masyarakat Indonesia adalah khitan perempuan.

Dari sini, dapat dipahami bahwa segala upaya pelarangan terhadap hal yang diyakini sebagai norma agama adalah inkonstitusional, melawan hukum, dan pelanggaran terhadap hak asasi manusia yang paling asasi, yakni hak beragama dan menjalankan ajaran agama sesuai dengan keyakinannya. Surat Edaran tentang Larangan Medikalisasi Sunat Perempuan termasuk di dalam bagian ini.

Penghargaan terhadap nilai agama dan keragaman budaya merupakan prinsip universal yang harus

\footnotetext{
${ }^{33}$ Lihat UU Nomor 7 Tahun 1984 tentang Pengesahan Konvensi Mengenai Penghapusan Segala Bentuk Diskriminasi Terhadap Wanita (CEDAW), bagian penjelasan umum pada alenia terakhir.
} 
diperhatikan dalam penetapan setiap kebijakan publik. Tradisi Barat yang setting sosialnya berbasis ajaran Kristiani akan sangat berbeda dengan cara pandang Islam dalam hal yang terkait dengan masalah keagamaan. Tradisi kristiani tidak mengenal ritual "khitan".

Dalam Islam, sebagaimana tergambar dalam pembahasan di atas, khitan termasuk kategori ibadah, baik bagi laki-laki maupun perempuan. Meski intensitas hukum taklîfi (pembebanan)-nya diperselisihkan, antara wajib, sunah, dan makrûmah.

Dan dalam kaidah hukum Islam, asal dari ibadah adalah bersifat ta'abbudî, dogmatik, al-Ghalib fi alibâdah al-ta'abbud wa al-tawqif ${ }^{44}$, yang dalam istilah filsafat hukum Islam disebut ghayr ma'qûlât al-ma'nâ (tidak dapat dirasionalisasi), meski tidak jarang ditemukan manfaat lahiriah atas pelaksanaan dogma tersebut, sebagaimana banyak ditemukan manfaat medis atas khitan bagi laki-laki.

Prinsip dari pelaksanaan ibadah yang dogmatik adalah ketundukan. Sekalipun tidak ditemukan manfaat medis sekalipun, sepanjang dalil agama menunjukkan adanya pensyariatan, maka ia tetap harus dilaksanakan.

Alasan mengenai tidak adanya manfaat medis atas khitan perempuan, sebagaimana termuat juga dalam Surat Edaran Dirjen Bina Kesehatan Masyarakat, bukan merupakan petunjuk atas terlarangnya khitan perempuan. Dalam bahasa usul fikih, "Ketiadaan dalil tidak dapat dijadikan dalil". Dalam konteks ini ketiadaan temuan medik mengenai manfaat atas pelaksanaan khitan perempuan bukan merupakan dalil atau alasan dilarangnya khitan perempuan.

Alasan ketiadaan prosedur medis ${ }^{35}$ dalam melakukan khitan perempuan untuk melarang khitan perempuan juga alasan yang musykil. Justru itulah, tenaga kesehatan dan instansi yang bertangung jawab di bidang medik ini memberikan prosedur medis, bukan justru menjadikannya alasan pelarangan. Batasan atau tata cara khitan terhadap perempuan secara fikih tersebut seharusnya dioperasionalisasi dalam bahasa medis, sehingga tidak terjadi benturan.

Ragam pemahaman tentang substansi khitan perempuan juga memiliki andil yang tidak kecil terhadap fenomena pelarangan khitan perempuan. Sebagaimana dalam konsepsi fikih tidak dijelaskan secara rinci mengenai tata cara khitan perempuan, pengertian sunat perempuan di dunia medik juga terjadi keragaman pemahaman, baik substansi maupun peristilahan. Dalam terminologi WHO, setidaknya ada

${ }^{34}$ Lihat antara lain dalam Ibn Daqî̀ al-'Id, Syarh 'Umdah alA $\underline{h a ̂ m}$, (Bayrût: Dâr al-Kutub al-'Ilmiyyah, t.th), Juz I, h. 172.

${ }^{35}$ Dapat dilihat dalam pertimbangan Surat Edaran Dirjen Bina Kesehatan Masayarakat angka 3. beberapa istilah yang digunakan, yakni: FGM (Female Genital Mutilation), FGC (Female Genital Cutting), Circumcision, dan FGM/C (Female Genital Mutilation/ Cutting), dan mendefinisikannya sebagai "all procedures involving partial or total removal of the external female genitalia or other injury to the female genital organs whether for cultural, religious or other non-therapeutic reasons ${ }^{136}$.

Dalam konteks Indonesia, rujukan pengertian yang sepadan dengan khitan perempuan dalam perspektiffikih juga tidak tunggal. Ditjen Bina Kesehatan Masyarakat Depertemen Kesehetan RI-termasuk pembuat TOR dari Kementerian Negara Pemberdayaan Perempuanmenerjemahkan khitan perempuan dengan FGM, dan diartikan sebagai "medikalisasi sunat perempuan".

Dari sisi kaidah bahasa Indonesia istilah female genital mutilation (mutilasi alat kemaluan perempuan), yang diterjemahkan dengan "medikalisasi sunat perempuan" kurang tepat. Medikalisasi tidak dikenal dalam istilah bahasa Indonesia. Yang ada adalah medikasi, yang berarti "terapi dengan pemberian obat medula" ${ }^{37}$.

Fransiska Lisnawati Kerong, menegaskan bahwa "Female Genital Mutilation (sunat perempuan) merupakan tindakan pemotongan sebagian atau seluruh organ genital perempuan, yang dilakukan pada bayi atau anak perempuan sebelum mencapai usia akhil balik" ${ }^{" 38}$. Definisi FGM yang seperti ini, tidak sejalan dengan pengertian sunat perempuan dalam perspektif fikih Islam. Pengertian ini menambah biasnya pengertian khitan perempuan.

Menerjemahkan Female Genital Mutilation (FGM) dengan istilah "Medikalisasi Sunat Perempuan", yang kemudian merujuk atas praktik khitan perempuan di negara Indonesia yang mayoritas Muslim, yang dengannya berarti merujuk pengertian khitan perempuan dalam perspektif hukum Islam, adalah tindakan yang sangat gegabah. FGM, singkatan dari Female Genital Mutilation, jika diartikan secara kebahasaan adalah mutilasi alat kemaluan perempuan. Mutilasi, kata serapan yang sudah menjadi bahasa Indonesia, sebagaimana dalam Kamus Besar Bahasa

36 Sebagaimana dikutip dalam Wikipedia, bersumber dari World Health Organization (2006-06-02). New study shows female genital mutilation exposes women and babies to significant risk at childbirth. Press release. http://www.who.int/mediacentre/news/releases/2006/pr30/en/ index.html

37 Departemen Pendidikan Nasional RI, Kamus Besar Bahasa Indonesia, (Jakarta: Pusat Bahasa-Balai Pustaka, 2007), Edisi III, Cet. VII, h. 726 .

${ }^{38}$ Fransiska Lisnawati Kerong, Female Genital Mutilation Ditinjau dari Aspek Hukum Perlindungan Perempuan dan Hak Asasi Manusia, (Jakarta: Fakultas Hukum UNIKA Atmajaya, 2008), sebagaimana diunduh dalam situs perpustakaan Fakultas Hukum Universitas Katolik Atmajaya. 
Indonesia berarti "proses atau tindakan memotongmotong (biasanya) tubuh manusia atau hewan". 39

Di sisi lain, Jurnalis Uddin dalam presentasi tentang "Sirkumsisi (Khitan) pada Perempuan" menyimpulkan bahwa Indonesia tidak memiliki tradisi Female Genital Mutilation (FGM).

Jika khitan perempuan dikategorikan sebagai mutilasi yang terlarang, maka logikanya sebenarnya khitan laki-laki lebih layak untuk dilarang, karena jelas-jelas memotong bagian dari kemaluan laki-laki dan membuangnya. Namun, tidak banyak yang berani mengampanyekan larangan khitan bagi laki-laki dan mengkategorikannya sebagai tindakan mutilasi yang melanggar HAM.

Apakah karena sudah banyak penelitian yang membuktikan mutilasi organ kelamin laki-laki ini dapat menghindarkan diri dari penyakit kelamin seperti kanker dan HIV, kemudian ia tidak dimasukkan sebagai "mutilasi" yang terlarang, sementara dalam hal "mutilasi" kelamin perempuan karena belum ada penemuan ilmiah, sehingga ia masuk kategori pelanggaran HAM?

Dugaan penulis, karena pelarangan khitan terhadap laki-laki akan membentur tembok besar keyakinan umat Islam yang sangat kuat. Walau demikian, American Medical Association (Asosiasi Medis Amerika) menyatakan bahwa perhimpunan kesehatan di Amerika Serikat, Australia, dan Kanada tidak merekomendasikan sunat rutin non-therapeutic pada bayi laki-laki ${ }^{40}$. Para pendukung integritas genital mengecam semua tindakan sunat pada bayi karena menurut mereka itu adalah bentuk mutilasi genital pria yang dapat disamakan dengan sunat pada wanita yang dilarang di AS.

Jika pelarangan khitan terhadap perempuan bersifat mutlak sebagaimana tergambar di atas, maka Fatwa MUI dapat menjadi benteng atas langkah-langkah sistemik tersebut, dan ia berada dalam posisi yang berhadapan dengan kelompok ini.

\section{Penutup}

Dari paparan di atas, dapat disampaikan beberapa kesimpulan, di antaranya: Pertama, dalam mazhab fikih yang utama, diperoleh konsensus bahwa tidak dibenarkan pelarangan khitan terhadap perempuan. Kedua, perlu ada pemahaman yang benar dan utuh terhadap terminologi khitan perempuan. Kesalahan konsepsi terhadap khitan perempuan akan melahirkan kebijakan yang salah pula. Penyamaan definisi khitan

\footnotetext{
39 Departemen Pendidikan Nasional RI, Kamus Besar Bahasa Indonesia, h. 768.

${ }^{40}$ Sebagaimana ditulis kembali oleh Warta Kota, "Tentang Sunat dan Khitan", dimuat pada Minggu, 5 April 2009, h. 6.
}

perempuan dalam konteks Indonesia yang berbasis norma agama Islam dengan Female Genital Mutilation (FGM) adalah tindakan yang ceroboh yang ahistoris. Penyebutan FGM dengan khitan/sunat perempuan dan medikalisasi sunat perempuan juga tindakan gegabah. Pandangan Jurnalis Uddin tidak menyamakan FGM dengan khitan perempuan dan menjelaskan bahwa di Indonesia tidak ada khitan perempuan model FGM.

Ketiga, Fatwa MUI tentang hukum pelarangan khitan terhadap perempuan punya dua dimensi, yakni (1) penegasan dan respons atas gerakan pelarangan khitan terhadap perempuan secara mutlak. MUI menilai bahwa pelarangan khitan terhadap perempuan adalah bertentangan dengan ketentuan syariah, melanggar konstitusi, dan melanggar hak asasi manusia yang paling dasar, yakni hak kebebasan beragama dan menjalankan agamanya. (2) penegasan akan pentingnya regulasi dan sosialisasi atas praktik khitan terhadap perempuan yang berar secara syar'i dan aman secara medik, sehingga tidak mendatangkan bahaya bagi perempuan.

Keempat, Fatwa MUI dapat dijadikan pegangan bagi kelompok masyarakat yang memiliki perhatian tulus terhadap pemenuhan hak-hak dasar kemanusiaan, pemenuhan perlindungan hak perempuan dan hak reproduksi untuk bersama-sama menyusun kerangka kerja mengadvokasi masyarakat agar dapat menghindarkan diri dari penyimpangan praktik khitan, dengan menyusun standar aman (secara medis) dan benar (secara syariah) dalam praktik khitan bagi perempuan.

Kelima, Fatwa MUI tentang khitan perempuan ini berhadapan secara diametral dengan kelompok masyarakat yang memaksakan diri untuk melakukan pelarangan khitan terhadap perempuan secara mutlak. Tindakan tersebut bertentangan dengan ketentuan syariah dan nilai universal hak asasi manusia, serta melanggar konstitusi negara. []

\section{Pustaka Acuan}

\section{Buku}

'Id, al-, Ibn Daqiq, Syarh 'Umdah al-Ahkâm, Bayrût: Dâr al-Kutub al-'Ilmiyyah, t.th.

Amaliah, Lila, "Pelaksanaan Sunat Perempuan di Indonesia", hasil penelitian Population Council di Enam Propinsi, 2001-2003, makalah presentasi pada 5 September 2006.

'Asqalânî, al-, ibn Hajar, Fath al-Bârî, Bayrût: Dâr alMa'rifah, $1379 \mathrm{H}$.

Bukhârî, al-, Shahîh al al-Bukhârî. Bayrût: Dâr al-Fikr, t.th.

Departemen Pendidikan Nasional RI, Kamus Besar Bahasa Indonesia, Jakarta: Pusat Bahasa-Balai 
Pustaka, 2007, Edisi III, Cet. VII.

Dirjen Bina Kesehatan Masyarakat Departemen Kesehatan, "Kebijakan Departemen Kesehatan dalam Menyikapi Praktik Sunat Perempuan", makalah presentasi.

Fathullah, Ahmad Luthfi, "Fikih Khitan Perempuan", bahan presentasi, tidak diterbitkan.

Hawasyi al-Syarwani, Bayrût: Dâr al-Fikr, t.th.

Himpunan Fatwa Majelis Ulama Indonesia, Jakarta: Sekretariat MUI-Departemen Agama RI, 2003.

I'anah al-Thalibin, Bayrût: Dâr al-Fikr, t.th.

Ibn Hanbal, Imam Ahmad, Musnad Ahmad ibn Hanbal, Mesir: Muassasah Qurthubah, tt.


Risâlah, 1993, Cet. II.

Ibn Mâjah, Muhammad ibn Yazîd Abû 'Abd Allâh, Sunan Ibn Mâjah, Bayrût: Dâr al-Fikr, t.th.

Ibn Rusyd, Bidâyah al-Mujtahid, Bayrût: Dâr al-Fikr, t.th.

Ibn Taymiyyah, Kutub wa Rasâil wa Fatâwâ Ibn Taymiyyah fi al-Fiqh, t.tp: Maktabah Ibn Taymiyyah, t.th.

, Majmî̀ Fatâwâ, al-Qâhirah, Maktabah Ibn Taymiyyah, t.th.

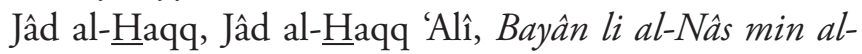
Azhâr al-Syarîf, al-Qâhirah: Mathba'ah al-Azhâr, 1989.

Kerong, Fransiska Lisnawati, Female Genital Mutilation Ditinjau dari Aspek Hukum Perlindungan Perempuan dan Hak Asasi Manusia, Jakarta: Fakultas Hukum UNIKA Atmajaya, 2008.

Malaybarî, al-, Zayn al-Dîn, Fath al-Mu'in, Bayrût: Dâr al-Fikr, t.th.

Maqdisî, al-, Ibn Qudâmah, al-Mughnî, Bayrût: Dâr al-Fikr, $1405 \mathrm{H}$, cet. I, edisi CD dalam Maktabah .al-Fiqh wa Ushûlih

Minhâj al-Thâlibîn, Bayrût: Dâr al-Ma'rifah, t.th.

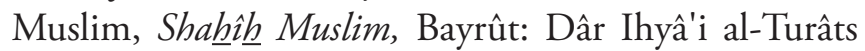
al-'Arabî, t.th.

Nawawî, al-, Abû Zakariyâ Muhy al-Dîn ibn Syaraf, Rawdhah al-Thâlibîn, Bayrût: al-Maktab al-Islâmî, 1405 H, cet. II, edisi CD dalam Maktabah al-Fiqh wa Ushûlih.

---------, al-Majmûu, Bayrût: Dâr al-Fikr, 1996, cetakan I.

Qaradhawî, al-, Yûsuf, al- $\underline{H} u k m$ al-Syar'î fi Khitân alInâts, sebagaimana dimuat dalam situs resminya.

Qurthûbî, al-, Tafīir al-Qurthîbî, Bayrût: Dâr al-Ihyầ al-Turâts al-'Arabî, 1957 M.
Sentika, Rachmat, "Larangan Melakukan Sunat Bagi Perempuan", bahan presentasi yang ditulis tahun 2006, tidak diterbitkan.

Shan'ânî, al-, Muhammad ibn Ismâ'îl, Subul al-Salâm, tahqîq Muhammad 'Abd al-'Azîz al-Khûlî, Bayrût: Dâr Ihyâ'i al-Turâts al-'Arabî, 1379 H, cet. IV.

Sijistani, al-, Imâm Abû Dâwûd Sulaymân ibn alAsy'ats, Sunan Abî Dawûd, Suriah: Dâr al- $\underline{\text { Hadîts, }}$ 1389 H/1969 M, cet. I dan cet. Bayrût: Dâr al-Fikr, t.th.

Syâfi'î, al-, Muhammad ibn Idrîs, al-Umm, Bayrût: Dâr al-Ma'rifah, $1393 \mathrm{H}$, cet. II.

Syairâzî, al-, Abû Ishâa Ibrâhîm, al-Muhadzdzab, Bayrût; Dâr al-Fikr, t.th.

Syarbini, al-, Muhammad al-Khathib, Mughni alMuhtaj, Bayrût: Dâr al-Fikr, t.th.

Syawkânî, al-, Fath al-Qadir, Bayrût: Dâr al-Fikr, t.th.

----------, Nayl al-Awthâr, Bayrût: Dâr al-Jail, 1973.

Tuhfah al-Ahwadzî, Bayrût: Dâr al-Kutub al-'Ilmiyyah, t.th.

Turmudzî, al-, Muhamamad ibn 'Îsâ Abû 'Îsâ, Sunan al-Turmudzî̀, Bayrût: Dâr Ihyâ' al-Turâts al-'Arabî, t.th.

Uddin, Jurnalis, "Sirkumsisi (Khitan) pada Perempuan", makalah presentasi pada September 2006, tidak diterbitkan.

Zuhaylî, al-, Wahbah, al-Figh al-Islâmî wa Adillatuh, Bayrût: Dâr al-Fikr al-Mu'âshir, 1998.

---------, al-Tafsîr al-Munîr fi al-'Aqîdah wa al-Syarî'ah wa al-Manhaj, Damaskus: Dâr al-Fikr, 1998.

Surat Edaran tentang Larangan Medikalisasi Sunat Perempuan bagi Petugas Kesehatan yang ditandatangani oleh Dirjen Bina Kesehatan Masyarakat Depkes pada 20 April 2006.

\section{Peraturan dan Perundang-undangan}

UU RI Nomor 23 tahun 2004 tentang Penghapusan Kekerasan Dalam Rumah Tangga

UU RI Nomor 32 Tahun 2002 tentang Perlindungan Anak.

UU RI Nomor 7 tahun 1984 tentang Pengesahan Konvensi Mengenai Penghapusan Segala bentuk Diskriminasi terhadap Wanita.

\section{Website dan Media Massa:}

http://en.wikipedia.org

http://www.who.int

http://www.ahlalhdeeth.com.

Harian Warta Kota pada Minggu, 5 April 2009. 
46 Ahkam: Vol. XII, No. 2, Juli 2012 